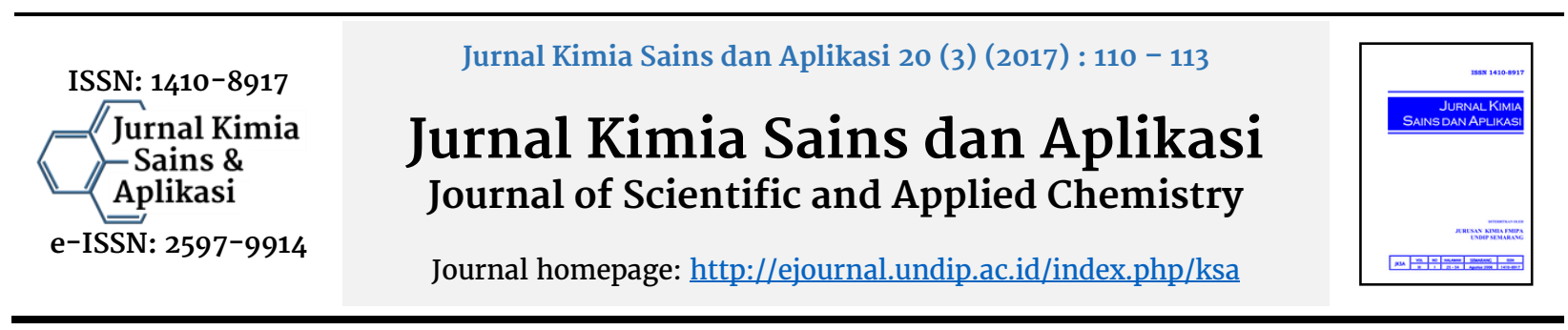

\title{
Encapsulation of Alkaline Phosphatase in Mesoporous Methyl- Silica Hybrid by Sol-Gel Process
}

\author{
Sriyanti $\mathrm{a}^{\mathrm{a}^{*}}$ \\ a Inorganic Chemistry Laboratory, Chemistry Department, Faculty of Sciences and Mathematics, Diponegoro University, Jalan Prof. \\ Soedarto, Tembalang, Semarang 50275 \\ * Corresponding author: sriyanti@live.undip.ac.id
}

\begin{tabular}{|c|c|}
\hline Article Info & Abstract \\
\hline $\begin{array}{l}\text { Keywords: } \\
\text { encapsulation, } \\
\text { alkaline } \\
\text { phosphatase, } \\
\text { methyl-silica } \\
\text { hybrid, sol-gel }\end{array}$ & $\begin{array}{l}\text { In recent years, the sol-gel technique has attracted increasing interest as a unique } \\
\text { approach to immobilize biomolecules for bioanalitical applications as well as } \\
\text { biochemical and biophysical studies. In this research, encapsulation of Alkaline } \\
\text { Phosphatase (ALP) enzyme in mesoporous methyl-silica hybrid by sol-gel process has } \\
\text { been carried out. Mesoporous methyl-silica hybrid has been synthesis by using } \\
\text { tetraethylorthosilicate (TEOS) and methyltriethoxysilane (MTES) as precursor and } \\
\text { poly(ethylene) glycol (PEG) as a polymer dopant. The preparation of methyl-silica } \\
\text { hybrid was carried out at various mol ratios of precursors and PEG concentration. } \\
\text { Encapsulation was emphasized by mixing sol solution and tris-HCl buffer containing } \\
\text { ALP. The Surface Area Analyzer analysis data showed that the pore diameter and surface } \\
\text { area of methyl-silica hybrid tended to increase as the PEG dopant concentration } \\
\text { increases. Result showed that ALP encapsulated in the methyl-silica hybrids with PEG } \\
\text { dopant gave enzymatic activity as o.112 U/mg enzyme, higher than ALP encapsulated in } \\
\text { copolymerization of TEOS with MTES or in silica from TEOS precursor only (o.o98 U/mg } \\
\text { enzyme and o.o69 U/mg enzyme, respectively). It was shown that copolymerization of } \\
\text { TEOS with organosilane precursor and the entrapment of polymer additives into sol-gel } \\
\text { processed materials are useful methods for modifying the internal environment and } \\
\text { hence the activity of biomolecules entrapped in sol-gel derived biomaterials. }\end{array}$ \\
\hline
\end{tabular}

\section{Introduction}

Encapsulation of biomolecules such as enzymes, proteins, cells and microorganisms in porous metal oxides by physical entrapment via sol-gel process has drawn great interest in recent years. The encapsulation of enzymes by sol-gel methods is commonly carried out through four stages, namely acid catalyzed hydrolysis of alkoxysilane precursors, addition of aqueous buffer solution containing enzyme, aging and drying to produce optically transparent glass materials with the enzyme entrapped [1-3].

The entrapment of protein into a silica matrix can result in a range of possible environments for the entrapped protein. Some of the proteins are entrapped in pores which are completely accessible to the analyte, some in the pores that are partially accessible, while the reminder of the protein may be sequestered into pores which are completely inaccessible. Pore sizes of the silica matrices and analyte-matrix interactions such as electrostatic, hydrogen bonding and hydrophobic interactions play an important role in determining the accessibility of an analyte to entrapped proteins $[4,5]$. Therefore, in order to maximize the accessibility, some modifications should be employed including manipulation of sol-gel synthesis conditions, incorporation of polymer or other additives, manipulation of aging conditions to minimize silanol content, manipulation of $\mathrm{pH}$ conditions or use of templating agents to promote larger pores (mesopores) [6].

In this research, encapsulation of Alkaline Phosphatase (ALP) enzyme in mesoporous methyl-silica hybrid by sol-gel process has been carried out. Mesoporous methyl-silica hybrid has been synthesis by using tetraethylorthosilicate (TEOS) and methyltriethoxysilane (MTES) as precursor and poly(ethylene) glycol (PEG) as a polymer dopant. 


\section{Experimental}

Material and Methods: Alkaline phosphatise (ALP) (EC 3.1.3.1, type I-S, from bovine intestinal mucosa), bovine serum albumin (BSA), p-nitrophenyl phosphate, tris-HCl buffer, glycin buffer were supplied by Sigma. Tetraethylorthosilicate (TEOS), Methyl triethoxysilane (MTES) and polyethylene glycol (PEG, MW 600) were purchased from Sigma.

The preparation of alkaline phosphatase, ALP, immobilized silica sol-gel materials followed procedures of Avnir dkk. [2], Keeling-Tucker dkk. [6], and Wei $d k k$. [5], with some modification.

Preparation of polymer template containing silica sol-gel material.

In this work, PEG 600 and PVA 13,000-23,000 used as templates. Typically, TEOS was prehydrolyzed with water in ethanol using $\mathrm{HCl}$ as catalyst at [TEOS]:[ $\left.\mathrm{H}_{2} \mathrm{O}\right]:[\mathrm{EtOH}]:[\mathrm{HCl}]$ molar ratio of 1:4:3:0.0005 under magnetic stirring at room temperature. After 30 minutes, the precursors mixture became homogenous. The hydrolyzed solution was stored for 3 days in a freezer before use to ensure complete hydrolysis. Furthermore, the prehydrolyzed solution was added to a specific amount of aqueous template solution ranging from 10 to $40 \mathrm{wt} \%$. the resultant homogenous sol was sealed with paraffin film containing several pinholes to allow for slow evaporation of solvents and reaction by products at room temperature.

To prepare the mesoporous silica material, the sample was ground and extracted with water to remove the template from the synthesized silica materials at room temperature. A certain amount of sample (e.g 0.2$1.0 \mathrm{~g}$ depending on the template content) was ground into powder, which was soaked in $15 \mathrm{~mL}$ water under stirring for 30 minutes. After centrifugation and decantation, the sample was placed in another $15 \mathrm{~mL}$ of fresh water for $3 \mathrm{~h}$. The mixture was again centrifuged and soaked in $15 \mathrm{~mL}$ water overnight. In the following two days, the sample was washed twice a day in the same manner. After extraction, the sample was dried at room temperature.

Immobilisation of alkaline phosphatise in silica solgel material.

The ALP was added to the prehydrolized precursor before gelation. In a typical procedure for the preparation of enzyme-doped silica sol-gel: TEOS (2mL) was mixed with $\mathrm{H}_{2} \mathrm{O}(0.48 \mathrm{~mL})$ and $\mathrm{HCl}(0.015 \mathrm{~N}$, $16 \mu \mathrm{L})$ in a flask under sonication at room temperature for 30 minutes. A volume of $1.5 \mathrm{~mL}$ hydrolyzed TEOS was then mixed with $2.5 \mathrm{~mL}$ of a tris-HCl buffer ( $40 \mathrm{mM}, \mathrm{pH}$ 8.5) containing ALP (a tris- $\mathrm{HCl}$ buffer solution containing ALP prepared by dissolving $2 \mathrm{mg}$ of the ALP in tris- $\mathrm{HCl}$ buffer solution $40 \mathrm{mM}, \mathrm{pH} 8.5$ ) and between 0 and 20 weight $\%$ of PEG or PVA solution. The mixture was placed in a flask that was then sealed with paraffin film and allowed to gel at room temperature. Upon gelation, several small holes were punched in the paraffin film to allow the evaporation to solvents and put into vacuum dessicator and continually evacuated for 10 days at room temperature until constant weight was reached.

\section{Detection Method:}

Fourier transform infrared (FTIR) spectroscopy was used to characterize the presence of specific chemical groups in the materials and to monitor the template removal. The as-synthesized and water extracted samples were milled and mixed with dried $\mathrm{KBr}$ powder. FTIR spectra were obtained within the range 4000 and $400 \mathrm{~cm}^{-1}$.

\section{Activity assay for free and entrapped enzyme.}

General procedure for enzymatic activity asys of ALP in solution and in immobilized form were adapted from the literatures. Kinetic parameters for the free and immobilized enzymes were determined using Michaelis-Menten kinetic [5].

The initial activity of ALP was determined from the absorbance change at $405 \mathrm{~nm}$ by using a UV-Vis spectrometer. The absorbance increase was due to the formation of p-nitrophenol. For free ALP, $1 \mathrm{~mL}$ of the enzyme solution (containing $2 \mu \mathrm{g}$ ALP) was mixed with $1.46 \mathrm{ml}$ of tris- $\mathrm{HCl}$ buffer and $0.3 \mathrm{~mL}$ of $\mathrm{MgCl}_{2} 0.01 \mathrm{M}$. After 30 minutes, $0.24 \mathrm{~mL}$ of $\mathrm{p}$-nitrophenyl phosphate $0.1 \mathrm{~m}$ was added to initiate reaction, upon which the absorbance change with time was recorded. For immobilized ALP, all samples were first washed with dilute buffer solution before proceeding with the activity assay according to the following procedure. The sample (containing 0.08 units of ALP) was weight into a tube and $10 \mathrm{~mL}$ tris- $\mathrm{HCl}$ buffer was added to soak the sample under agitation. After $1 \mathrm{~h}$, the washed solution was separated from the solid by decantation after centrifugation. The washing procedure was repeated two more times at $1 \mathrm{~h}$ intervals. The ALP containing gel was then evaluated for the apparent activity following the same procedure as for the free ALP except substituting the enzyme solution with $1 \mathrm{~mL}$ of $\mathrm{H}_{2} \mathrm{O}$. The sample was weighed into the assay mixture consisting of $1 \mathrm{mM}$ of $\mathrm{MgCl}_{2}$ and $40 \mathrm{mM}$ of tris- $\mathrm{HCl}$ buffer $\mathrm{pH}$ 8.5. The assays were performed at room temperature.

The kinetic parameters were determined by varying the concentration of substrate, p-nitrophenyl phosphate (p-NPP), from 1 to $15 \mathrm{mM}$. The effect of $\mathrm{pH}$ on the catalytic activity of ALP in free and encapsulated form was evaluated by measuring initial velocity of the reaction in buffers at different $\mathrm{pH}$ using fixed concentration of p-NPP ( $8 \mathrm{mM})$. The buffers used were $40 \mathrm{mM}$ tris- $\mathrm{HCl}$ buffers at $\mathrm{pH}$ values 7 to 8.5 at 0.5 intervals and glycin buffer for $\mathrm{pH}$ values 9 to 10 .

\section{Results and Discussion}

The preparation of enzyme containing sol-gel materials was performed by adding the enzymes with PEG as template, into The hybrids TEOS-MTES derived sol before gelation, followed by aging and drying the gel to yield the transparent enzyme-containing glasses. The gelation time was shortened by the addition of the buffered enzyme solution which raised the $\mathrm{pH}$ of the mixture. The aging and drying process were accelerated 
by using a vacuum dessicator to evacuate solvents and by-product of the sol-gel reaction without causing sample cracking which often occurs in a template free system.

The encapsulation of protein by sol-gel methods is commonly carried out through four stages, namely acid catalyzed hydrolysis of alkoxysilane precursors, addition of aqueous buffer solution containing protein, aging and drying to produce optically transparent glass materials with the protein entrapped $[4,5]$.

The structure and properties of doped sol-gels depend not only on the chemical composition of the starting materials, but also on many operational factors involved in the preparation. Upon immobilization, the entrapped biomolecules are expected to retain at least some of their functionality and storage stability. However, due to the complexity of the sol-gel reaction and the lack of fine structure control over the final product, it is desirable to develop a general approach for the synthesis of bio-doped sol-gel materials with reproducible performance and long term stability $[1,3]$.

A number of possibilities may occur to entrapped protein depending on the nature of the protein and the sol-gel precursors used, including homogeneously dispersing in the pore solvent, adsorbing into the silica surface, partitioning into specific phases within the nanocomposite materials, or aggregation. Jin dan Brennan [4] suggested that the entrapped protein are not simply present in solution-like environments but they can interact with matrix and show a distribution of dynamic motions, stabilities and binding constant that change as the material ages.

The entrapment of protein into a silica matrix can result in a range of possible environments for the entrapped protein. ${ }^{18}$ Some of the proteins are entrapped in pores which are completely accessible to the analyte, some in the pores that are partially accessible, while the reminder of the protein may be sequestered into pores which are completely inaccessible. Pore sizes of the silica matrices and analyte-matrix interactions such as electrostatic, hydrogen bonding and hydrophobic interactions play an important role in determining the accessibility of an analyte to entrapped proteins [5, 6]. Therefore, in order to maximize the accessibility, some modifications should be employed including manipulation of sol-gel synthesis conditions, incorporation of polymer or other additives, manipulation of aging conditions to minimize silanol content, manipulation of $\mathrm{pH}$ conditions or use of templating agents to promote larger pores (mesopores) [5].

Non-ionic biocompatible compounds such as glycerol and d-glucose were used as pore templates for enzymes encapsulation, such as alkaline phosphatase (ALP), acid phosphatase (ACP) and horseradish peroxidase (HRP). The entrapped enzymes demonstrated much higher remaining activities (enzymatic activity is increased by a factor of 2 to 10) and thermal stability than in non-templated samples prepared under the same conditions. ${ }^{8}$ While, uncharged polymeric dopants, PVA and PEG were used as templates for lipase encapsulation. The entrapped lipase showed dramatically enhanced of enzymatic activity than in convensional encapsulaton. Although immobilization of lipase was most successful, it was uncertained for the other enzymes because that biological molecules are not generic but form numerous classes of diverse compounds, which not only differ in their function but also in their structure and environment in vivo. Therefore, interested to study influence of addition PEG or PVA polymer in other enzyme encapsulation such as alkaline phosphatase. This enzyme has been used in biosensor for the determination of pesticides and heavy metals.

Enzymatic Reaction of alkaline phosphatase:

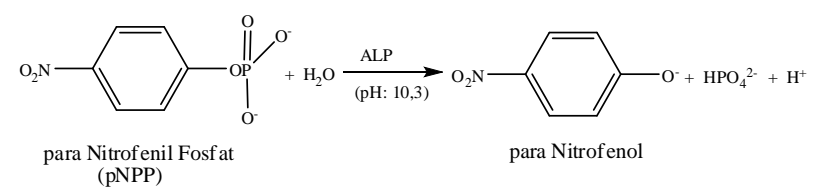

Table 1. BET surface area analysis datas

\begin{tabular}{cccc}
\hline Sample & $\mathrm{S}_{\mathrm{BET}}\left(\mathrm{m}^{2} / \mathrm{g}\right)$ & $\begin{array}{c}\text { Total pore } \\
\text { volume } \\
\left(\mathrm{cm}^{3} / \mathrm{g}\right)\end{array}$ & $\begin{array}{c}\text { Mean pore } \\
\text { radius }(\AA)\end{array}$ \\
\hline $\begin{array}{c}\text { Silika Gel } \\
\text { (SG) }\end{array}$ & 423 & 0,219 & 11,2 \\
SG-MTES & 391 & 0,208 & 14,4 \\
SG-PEG & 874 & 0,423 & 12,5 \\
\hline
\end{tabular}

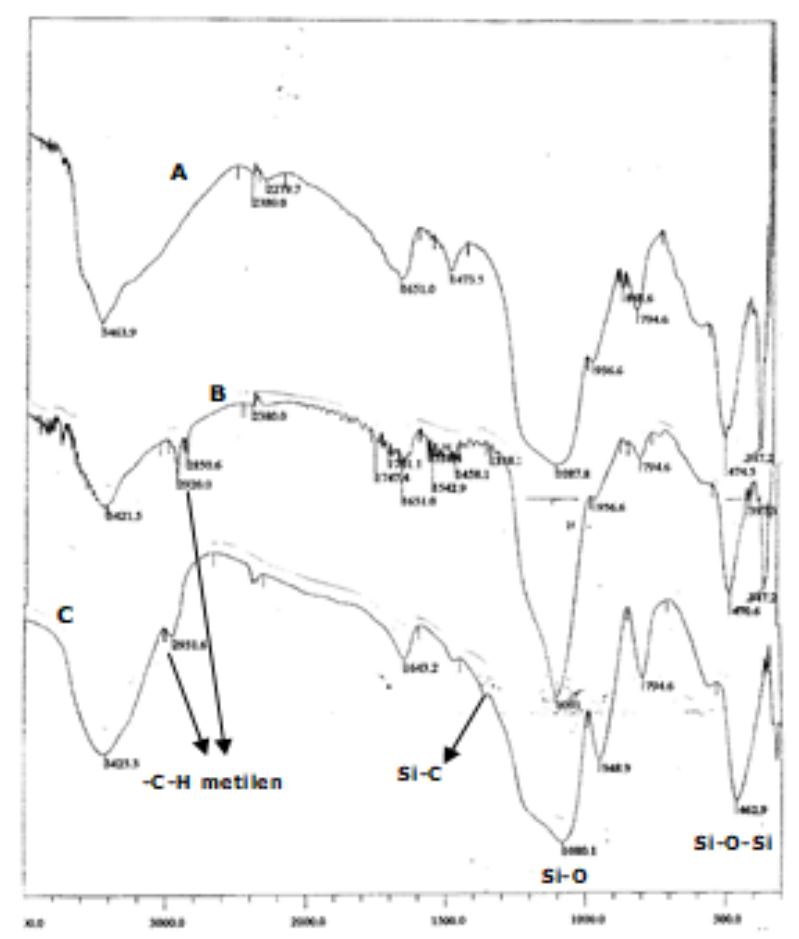

Figure 1. FTIR spectra from: A. Silika gel, B. Silika gelPEG dan C. Silika gel-MTES. 


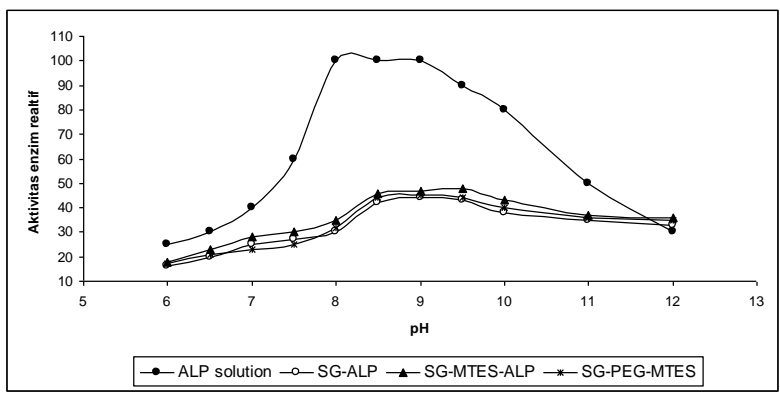

Figure 2. Influence of $\mathrm{pH}$ for enzymatic activity of ALP in silica-PEG and Silica-MTES.

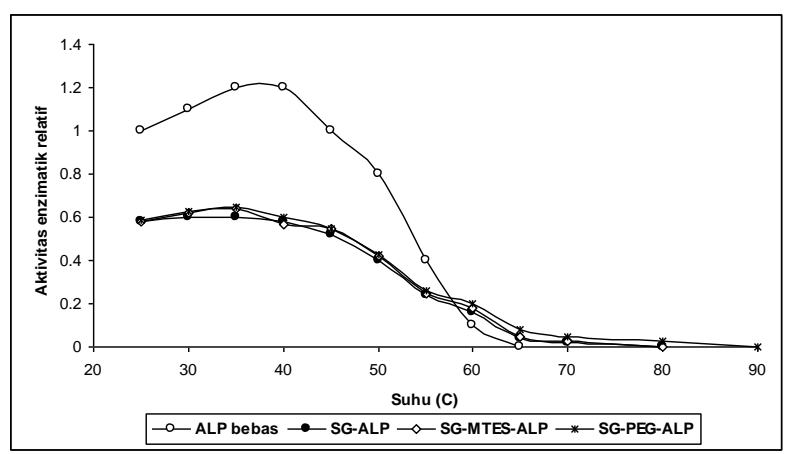

Figure 3. influence of temperature.

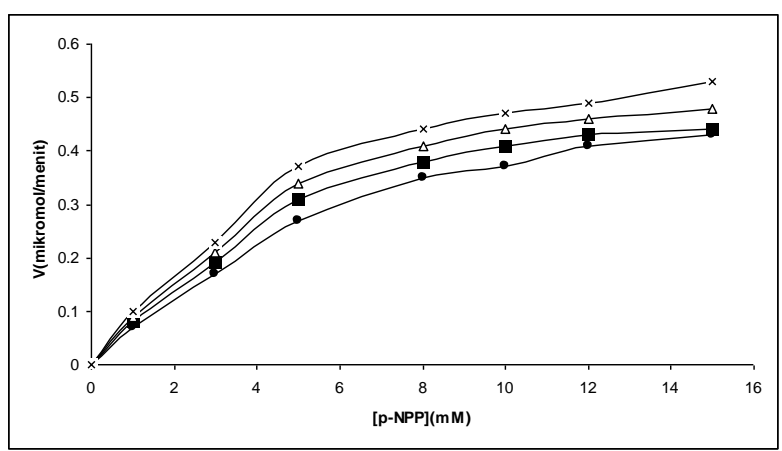

Figure 4. Michaelis-Menten curve for entrapped alkaline phosphatase in : (•) SG-ALP, (•) SG-5\%PEG, $(\diamond)$ SG-10\%PEG dan (x) SG-20\%PEG.

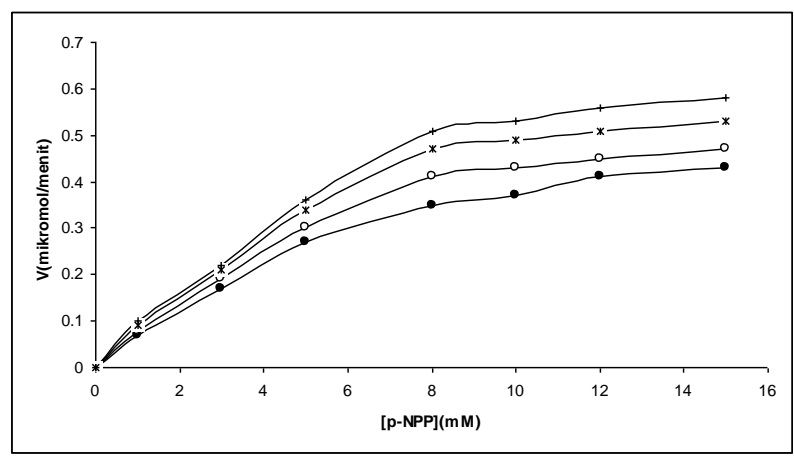

Figure 5. Michaelis-Menten curve from entrapped alkaline phosphatase in: (•) SG-ALP, (०) SG-10\%MTES, (*) SG-20\%MTES dan (+) SG-40\%MTES.
Table 2. enzymatic activity datas.

\begin{tabular}{|c|c|c|c|c|}
\hline No. & $\begin{array}{l}\text { ALP enzyme } \\
\text { in: }\end{array}$ & $\begin{array}{l}\mathrm{Km} \\
(\mathrm{mM})\end{array}$ & $\begin{array}{c}\text { Vmax } \\
(\mu \mathrm{M} / \text { minute })\end{array}$ & $\begin{array}{l}\text { Spesific actv. ( } \mu \text { mol } \\
\left.\text { menit }^{-1} / \mathrm{mg} \text { enzim }\right)\end{array}$ \\
\hline 1. & Solution & 0,077 & 6,988 & 3,494 \\
\hline 2. & SG & 9,563 & 0,738 & 0,069 \\
\hline \multirow[t]{3}{*}{3.} & SG-5\%MTES & 8,366 & 0,749 & 0,090 \\
\hline & $\begin{array}{l}\text { SG-10\% } \\
\text { MTES }\end{array}$ & 7,618 & 0,775 & 0,093 \\
\hline & $\begin{array}{l}\text { SG-20\% } \\
\text { MTES }\end{array}$ & 7,105 & 0,809 & 0,098 \\
\hline \multirow[t]{3}{*}{4.} & $\begin{array}{l}\text { SG- MTES- } \\
5 \% \text { PEG }\end{array}$ & 9,153 & 0,810 & 0,099 \\
\hline & $\begin{array}{l}\text { SG-MTES- } \\
10 \% \text { PEG }\end{array}$ & 9,321 & 0,925 & 0,103 \\
\hline & $\begin{array}{l}\text { SG-MTES- } \\
20 \% \text { PEG }\end{array}$ & 8,552 & 0,945 & 0,112 \\
\hline
\end{tabular}

\section{Conclusion}

Result showed that ALP encapsulated in the ethylsilica hybrids with PEG dopant gave enzymatic activity as $0.112 \mathrm{U} / \mathrm{mg}$ enzyme, higher than ALP encapsulated in copolymerization of TEOS with MTES or in silica from TEOS precursor only (0.098 U/mg enzyme and 0.069 $\mathrm{U} / \mathrm{mg}$ enzyme, respectively). It was shown that copolymerization of TEOS with organosilane precursor and the entrapment of polymer additives into sol-gel processed materials are usefull methods for modifying the internal environment and hence the activity of biomolecules entrapped in sol-gel derived biomaterials.

\section{References}

[1] John D. Brennan, Using Intrinsic Fluorescence to Investigate Proteins Entrapped in Sol-Gel Derived Materials, Applied Spectroscopy, 53, 3, (1999) 106A121A http://dx.doi.org/10.1366/0003702991946514

[2] David Avnir, Sergei Braun, Ovadia Lev, Michael Ottolenghi, Enzymes and Other Proteins Entrapped in Sol-Gel Materials, Chemistry of Materials, 6, 10, (1994) http://dx.doi.org/10.1021/cmoo046a008

1605-1614

[3] Bakul C. Dave, Bruce Dunn, Joan Selverstone Valentine, Jeffrey I. Zink, Sol-gel encapsulation methods for biosensors, Analytical Chemistry, 66, 22, (1994) http://dx.doi.org/10.1021/ac00094a001

[4] Wen Jin, John D. Brennan, Properties and applications of proteins encapsulated within solgel derived materials, Analytica Chimica Acta, 461, 1, (2002) 1-36 https://doi.org/10.1016/S00032670(02)00229-5

[5] Yen Wei, Jigeng Xu, Qiuwei Feng, Hua Dong, Muduo Lin, Encapsulation of enzymes in mesoporous host materials via the nonsurfactant-templated sol-gel process, Materials Letters, 44, 1, (2000) 6-11 http://dx.doi.org/10.1016/S0167-577X(99)00287-6

[6] Tracey Keeling-Tucker, Michael Rakic, Cassandra Spong, John D. Brennan, Controlling the Material Properties and Biological Activity of Lipase within Sol-Gel Derived Bioglasses via Organosilane and Polymer Doping, Chemistry of Materials, 12, 12, (2000) http://dx.doi.org/10.1021/cmoo0491m
3695-3704 